\title{
Ecological Architecture Concept in Campus Building in Indonesia
}

\author{
Jarwa Prasetya Sih Handoko, ${ }^{1, *}$ \\ ${ }^{1}$ Architecture Department, Universitas Islam Indonesia, Yogyakarta, Indonesia
}

\begin{abstract}
Sustainability is the development concept that meets condition of the present without compromising the ability of future generations to meet their own requirements on social, environmental and economical aspect. Ecological architecture is the concept of sustainable development emphasizes on environmental aspect that emphasize harmony between the built environment and the natural conditions in the surrounding areas such as waste and recycling, energy efficiency, water resource, building design, carbon emission, and aims to eliminate negative environmental impact while continuing to be completely sustainable. The university campus is one of the buildings used by the public. In keeping with his character university campus used by many people that require large energy consumption. So that was included in the building that need to be controlled levels of energy consumption. The campus building should consider harmony with the natural conditions around the building. Therefore, it is necessary to have a study that evaluates the application of ecological architecture concept in university campus in Indonesia. This study is a comparative study conducted descriptive methods related to the characteristics of the application of the ecological architecture concept in the design of university campus in Indonesia. This study takes a case study three university campuses in Indonesia which is included in the green campus in Indonesia. With this paper is expected to provide a general description of the application of the ecological architecture concept in the university campus design in Indonesia. The conclusion from this study that the university campus in Indonesia have applied the concept of ecological architecture in several aspects. There are some similarities and differences in the application of some aspects. Recommendations from this study is that a university campus building design should be able to optimize the application of the concept of ecological architecture on all aspects of the design.
\end{abstract}

\section{Introduction}

Sustainability is a concept of development that continues to be adopted today to ensure the fulfillment of the needs of future generations. It is not only related to the handling of environmental issues, but also covers social and ecological aspects of the built environment.

* Corresponding author: jarwa.prasetya@uii.ac.id 
Ecological architecture is an architectural concept that emphasizes harmony between the built environment and the natural conditions in the surrounding areas such as waste and recycling, energy efficiency, water resource, building design, carbon emission, and is intended to eliminate the impact of environmental negative. It is also intended to achieve ecological sustainability.

The university campus is one of the buildings used by the public. In keeping with his character university campus used by many people that require large energy consumption. So that was included in the building that need to be controlled levels of energy consumption. The campus building should consider harmony with the natural conditions around the building. Therefore it is necessary to do a study evaluating the application of the concept of ecological architecture in college campus buildings in Indonesia. With this research is expected to provide a general description of the application of the concept of ecological architecture in the design of a college campus in Indonesia.

\subsection{Research Problem}

How the application of the concept of ecological architecture in university campus buildings as part of efforts to realize the sustainable campus in Indonesia?

\subsection{Aim}

Knowing how the application of the concept of ecological architecture in university campus building as part of efforts to realize the sustainable campus in Indonesia.

\section{Methods}

This research is a comparative study with descriptive methods were implemented related to the characteristics of the application of the ecological architecture concept in the university campus design in Indonesia. This study takes a case study five university campuses in Indonesia, which is included in the green campus in Indonesia UI recipients Greenmetric World University Ranking. This research is essentially research that seeks to know the description of how the application of the concept of ecological architecture in college campus buildings as part of efforts to realize the sustainable campus or green campus in Indonesia based on the parameters and indicators green campus UI Green Metric World University Ranking.

Comparative studies commonly used by social researchers in compiling scientific research with the generalization of cross-border research and not prone to ethnic social culture of a particular society (Bahry, 1995). The comparative study emphasizes social observation is not limited to one particular territory (Lipjhart, 1975). The comparative study as described by Hermann, helping Observator to connect concepts that form the theory with observable indicators, understand expectations theory that form and explain whether the theory can materialize as expected (Hermann, 2002).

The comparative study using some of the cases had a similar classification in a problem. Researchers then compared the comparative study of variables and variants that exist in such cases to be described similarities and differences. From these searches then researchers will be able to formulate the question of what and how to study different comparison with a case study that focuses solely on the decomposition of the case as research and analytics data is not interpreted by the authors directly (Bahry, 1995). However, not all cases can be compared in a comparative study. Cases taken in the 
comparative study should have similarities in some aspects and should have differences that can be compared.

\subsection{Research Scope}

The case studies in this study selected five (5) buildings college campuses in Indonesia who entered the UI Greenmetric World University ranked as follows:

a. Universitas Indonesia (UI) in Jakarta was ranked 33 in 2015.

b. Universitas Negeri Semarang (UNNES) in Semarang, was ranked to 63 in 2015.

c. State University Sebelas Maret (UMS) Surakarta, was ranked 97 in 2015.

d. Universitas Bengkulu (UNIB) Bengkulu, was ranked 184 in 2015.

e. Universitas Tanjungpura (UNTAN) Pontianak, West Kalimantan, was ranked 381 in 2015.

These five case studies above are scattered in several major cities in Indonesia. Thus representing a diversity of environmental conditions in Indonesia.

\section{Literature Review}

\subsection{Ecological Architecture}

According to Heinz Frick and Tri Hesti Mulyani (2006) the development of ecological architecture can be traced from various approaches beginning in the 1920s to 1960s that prioritize freedom of expression in form and function. Sue Roaf (2005) conveyed that because of the influence of climate, there is a tendency for dynamics to change the development paradigm. The building paradigm shift from active building design concept leads to a more environmentally friendly passive building design. The process continues and is named as 'natural law'. (Frick, 1998).

Ulla Myhr and Rolf Johannson (2008) states the linkage of impacts caused by the development of the environment, that impact not only affects the physical in the environment but also affect the environment, but also affect the environment in the building both internal and external. The building naturally air refresher attention can save a lot of energy. The term ecology first introduced by Ernst Haeckel, an expert of zoology in 1869 as a science of the interaction of all living species and the environment. Ecology is usually understood as the things that are affecting all types of living things (plants, animals, human beings) and the environment (light, temperature, precipitation, humidity, topography, etc.). Similarly, the process of birth, life, alternation of generations, and death are all part of human knowledge.

Meanwhile, According to Yeang (1995) convey that Ecological design is bioclimatic design, design with the climate of the locality and low energy design. Emphasizing the integration of local ecological conditions, macro and micro climates, site conditions, building programs, climate design concepts and systems, low energy use. While the use of energy in buildings Yeang (1995) states that the use of energy in buildings caused by several processes: (1) Exploration, exploitation and processing of building materials. (2) manufacture and fabrication of building materials, (3) Distribution of materials and building materials to construction sites, (4) Building Construction, (5) Building Operations, (6) Maintenance of buildings and waste treatment.

Ecology can be defined as the study of the interrelationships between living things and their environment ( Frick, 1998 ). Actually, eco-architecture contains also the parts of the biological architecture, architecture alternative, architecture sun, architecture bionic, as well 
as the biological development. Eco-architecture does not specify what should happen in architecture because there is no binding characteristics as standard or standard size. However, eco-architecture includes the harmony between man and his natural environment.

Heinz Frick (1998) argues that the ecological architecture does not specify what should happen in architecture, because there is no binding characteristics as a standard or standard size. However covers harmony between man and nature. Ecological architecture contains also the dimension of time, the natural, socio-cultural, space and building techniques. Therefore, a holistic ecological architecture is a very broad term and contains all the fields. The principle of building ecological architecture according to Frick (1998), among others :

1. Adjustments to the local natural environment.

2. Conserve natural energy sources are not renewable and energy savings.

3. Maintaining the source environment (air, soil, water), maintain and improve the natural circulation.

4. Reduce dependence on the central system and wastes energy.

5. Possible occupants generate their own daily needs.

6. Utilizing the natural resources around the area of planning for building systems.

Both related to construction materials or for building utilities (energy sources and energy supply)

\subsection{Ecological Architecture Concept}

Ecological building criteria according to Frick (1998) are :

1. Creating a green area between the building area.

As one of the prevention of global warming and also as an interesting view for anyone who sees. For example creating a green area around the building is creating an ecological park around the building, urban farming (urban agriculture).

2. Choose the appropriate building site.

The footprint used in accordance with the project is built, but still by looking at the continuity between the environment and the building. Things to consider in choosing the appropriate site are:

a. The fertile land should be preserved for unused land for cultivated land.

b. Planted land should be mantained.

3. Using locally made building materials.

Currently, many ecologically-developed building materials include regenerative building materials, reuse materials, recycling materials, natural building materials undergoing simple transformation, natural building materials undergoing several levels of transformation changes and composite building materials. Ecological building materials have the following requirements:

a. Production of building materials uses as little energy as possible.

b. Not subject to change of material that can be returned to nature.

c. Exploitation, manufacture and use of building materials as little as possible pollute the environment.

d. Building materials come from local sources.

4. Using natural ventilation in buildings.

Ventilation from nature serves as a natural air exchange relating to indoor air quality. 2 matters relating to indoor air quality are natural air and natural lighting. 
5. Select the surface layer of the walls and ceiling of the room that is able to drain the water vapor.

6. Ensure that the building does not cause environmental problems.

A good building is a building that does not harm the environment, indeed when the building was built has reduced the animal community that previously existed on the land, but we as human beings who care about the environment should replace the land for their community by doing greening around the building. Among them with greening on buildings and garden design.

7. Using renewable energy.

Renewable energy is the energy generated by the building itself. Some renewable energy that can be implemented in buildings is the utilization of solar energy, water energy and wind energy.

8. Creating a barrier-free building

A good building is a building that can be used for all ages both children and parents, as well as all conditions including for the difable and healthy adults. Many of the obstacles in the current building include the difference in floor height, lack of clear orientation marks, no seat to rest.

According to Regulation of Minister of Public Work and RI No.02 Tahun 2015 about Green Building, there are 6 (six) main category of Green Building :

1. Land Development

2. Energy Efficient

3. Water Efficient

4. Building Material Cycle

5. Indoor Air Quality

6. Green Building Management.

\subsection{UI Green Metric World University Rangking parameter and Indicators.}

University of Indonesia (UI) initiated a world university ranking in 2010, later known as UI Green Metric World University Ranking, to measure environmental sustainability Efforts campus. It was intended to create an online survey to portray sustainability programs and policies in universities around the world (htpp://greenmetric.ui.ac.id).

Several parameters and indocators in the concept of ecological architecture derived from the above literature review roomates includes: Setting and Infrastructure, Energy and Climate Change, Waste, Water, Transportation and Education.

\section{Result and Discusion}

In this study conduct a comparative study on the application of the concept of ecological architecture building college campus in Indonesia. From the data obtained from the UI Green Metric World University Ranking 2015, it can be processed and analyzed as follows: 


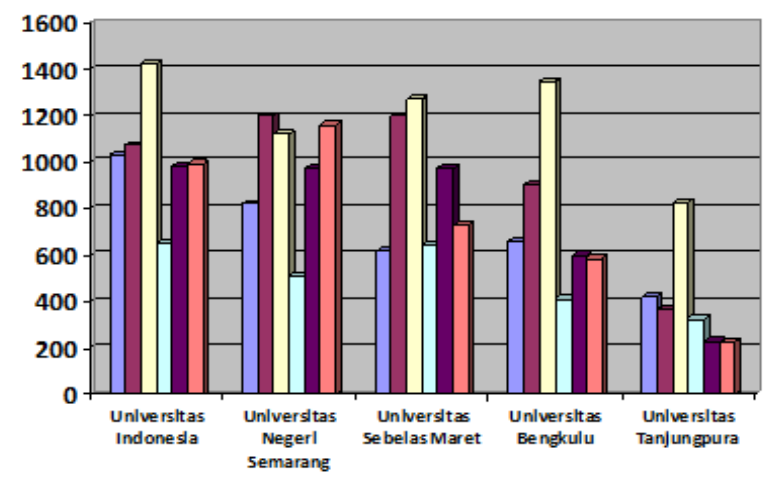

\begin{tabular}{|l|}
$\square$ Se tting and Infrastructure \\
$\square$ Energy and Climate Change \\
$\square$ W aste \\
$\square$ Water \\
$\square$ Transportation \\
$\square$ Education
\end{tabular}

Fig. 1. Architecture Ecology in Higher Education (Eco-Campus) based universities in Indonesia

From the diagram 4.1. above shows from various universities that are the case studies of the application of the concept of eco campus primarily implemented on waste management and waste college, then the application of the concept of energy saving and tackling climate change a priority second place. While the concept needs to be improved implementation is the concept of water conservation and sustainable management education.

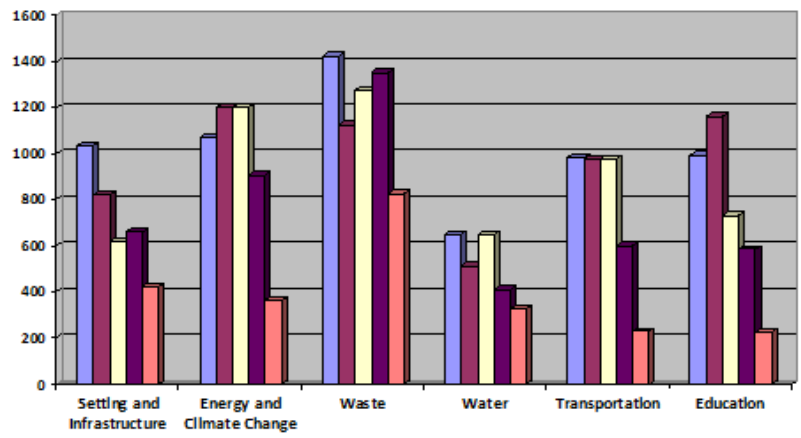

Dunlversitas indonesla

口unlversitas Negerl Semarang 口unlversitas Sebelas Maret घuniversitas Bengkulu Qunlversitas Tariungpura

Fig. 2. Architecture Ecology in Higher Education (Eco-Campus), based on the parameters of ecocampus in Indonesia

From the above comparative research data can be analyzed that not all parameters of the concept of eco-campus applied to all the colleges here at home. Application of the concept is done gradually adjust to the conditions of each college.

Primary data and secondary data obtained previously were then analyzed based on several criteria in the concept of ecological architecture derived from the above literature review which includes:

1. Setting and Infrastructure

2. Energy and Climate Change

3. Waste

4. Water

5. Transportation

6. Education 
Table 1. Comparison Application Architecture Concept of Ecology in Higher Education (Eco-Campus) in Indonesia.

\begin{tabular}{|c|c|c|c|c|c|}
\hline $\begin{array}{l}\text { Parameter and Indic } \\
\text { ator Eco-Campus }\end{array}$ & $\begin{array}{c}\text { Universitas } \\
\text { Indonesia (UI) }\end{array}$ & $\begin{array}{c}\text { Universitas Negeri } \\
\text { Semarang (UNNES) }\end{array}$ & $\begin{array}{c}\text { Universitas Negeri } \\
\text { Sebelas Maret } \\
\text { (UNS) }\end{array}$ & $\begin{array}{c}\text { Universitas } \\
\text { Bengkulu (UNIB) }\end{array}$ & $\begin{array}{l}\text { Universitas } \\
\text { Tanjungpura } \\
\text { (UNTAN) }\end{array}$ \\
\hline $\begin{array}{c}\text { Setting and } \\
\text { Infrastructure }\end{array}$ & $\begin{array}{l}\text { - Preparation of an } \\
\text { integrated campus } \\
\text { masterplan } \\
\text { - Determination of } \\
\text { Percentage of Green } \\
\text { Open Space } \\
\text { - Implementation of } \\
\text { Green Building } \\
\text { Concept. } \\
\end{array}$ & $\begin{array}{l}\text { - Preparation of an } \\
\text { integrated campus } \\
\text { masterplan } \\
\text { - Determination of } \\
\text { Percentage of Open } \\
\text { Space (RTH) } \\
\text { - Implementation of } \\
\text { Green Building } \\
\text { Concept } \\
\end{array}$ & $\begin{array}{l}\text { - Preparation of an } \\
\text { integrated campus } \\
\text { masterplan } \\
\text { - Determination of } \\
\text { Percentage of Green } \\
\text { Open Space. } \\
\text { - Implementation of } \\
\text { Green Building } \\
\text { Concept. } \\
\end{array}$ & $\begin{array}{l}\text { - Preparation of an } \\
\text { integrated campus } \\
\text { masterplan. } \\
\text { - Determination of } \\
\text { Percentage of Green } \\
\text { Open Space. } \\
\text { - Implementation of } \\
\text { Green Building } \\
\text { Concept. }\end{array}$ & $\begin{array}{l}\text { - Preparation of } \\
\text { integrated campus } \\
\text { masterplan. } \\
\text { - Implementation of } \\
\text { Green Building } \\
\text { Concept. }\end{array}$ \\
\hline $\begin{array}{l}\text { Energy and Climate } \\
\text { Change }\end{array}$ & $\begin{array}{l}\text { - Use lights and } \\
\text { energy efficient } \\
\text { appliances. } \\
\text { - Environmentally } \\
\text { friendly Material } \\
\text { - Optimizing Natural } \\
\text { lighting. } \\
\text { - Optimization of } \\
\text { Natural Cooling } \\
\text { - Vegetation }\end{array}$ & $\begin{array}{l}\text { - Biodiversity } \\
\text { - Use lights and } \\
\text { energy efficient } \\
\text { appliances. } \\
\text { - Environmentally } \\
\text { friendly Material } \\
\text { - Optimizing Natural } \\
\text { lighting. } \\
\text { - Optimization of } \\
\text { Natural Cooling. } \\
\text { - Vegetation }\end{array}$ & $\begin{array}{l}\text { - Biodiesel. } \\
\text { - Use lights and } \\
\text { energy efficient } \\
\text { appliances. } \\
\text { - Environmentally } \\
\text { friendly Material } \\
\text { - Optimizing Natural } \\
\text { lighting. } \\
\text { - Optimization of } \\
\text { Natural } \\
\text { Penghawaan. } \\
\text { - Vegetation }\end{array}$ & $\begin{array}{l}\text { - Use lights and } \\
\text { energy efficient } \\
\text { appliances. } \\
\text { - Optimizing Natural } \\
\text { lighting. } \\
\text { - Optimization of } \\
\text { Natural Cooling. } \\
\text { - Vegetation }\end{array}$ & $\begin{array}{l}\text { - Use lights and } \\
\text { energy efficient } \\
\text { appliances. } \\
\text { - Optimizing Natural } \\
\text { lighting. } \\
\text { - Optimization of } \\
\text { Natural Cooling. } \\
\text { - Vegetation }\end{array}$ \\
\hline
\end{tabular}




\begin{tabular}{|c|c|c|c|c|c|}
\hline Waste & $\begin{array}{l}\text { - Waste water treatment } \\
\text { and garbage. } \\
\text { - Paperless Policy }\end{array}$ & $\begin{array}{l}\text { - Waste water } \\
\text { treatment and } \\
\text { garbage. } \\
\text { - Paperless Policy } \\
\text { - Composting. }\end{array}$ & $\begin{array}{l}\text { - Waste water } \\
\text { treatment and } \\
\text { garbage. } \\
\text { - Paperless Policy } \\
\text { - Composting. }\end{array}$ & $\begin{array}{l}\text { - Waste water } \\
\text { treatment and } \\
\text { garbage. } \\
\text { - Paperless Policy }\end{array}$ & $\begin{array}{l}\text { - Waste water } \\
\text { treatment and } \\
\text { garbage. } \\
\text { - Paperless Policy }\end{array}$ \\
\hline Water & $\begin{array}{l}\text { - Water treatment. } \\
\text { - Creation of the lake } \\
\text { / reservoir in the } \\
\text { campus area as a } \\
\text { water reservoir. } \\
\text { - Preparation of rain } \\
\text { water infiltration. } \\
\text { - The use of } \\
\text { greywater and } \\
\text { Rainwater } \\
\text { harvesting. }\end{array}$ & $\begin{array}{l}\text { - Water treatment. } \\
\text { - Creation of the lake } \\
\text { / reservoir in the } \\
\text { campus area as a } \\
\text { water reservoir. } \\
\text { - Preparation of rain } \\
\text { water infiltration. } \\
\text { - The use of } \\
\text { greywater and } \\
\text { Rainwater } \\
\text { harvesting. } \\
\end{array}$ & $\begin{array}{l}\text { - Water treatment. } \\
\text { - Creation of the lake } \\
\text { / reservoir in the } \\
\text { campus area as a } \\
\text { water reservoir. } \\
\text { - Preparation of rain } \\
\text { water infiltration. } \\
\text { - The use of } \\
\text { greywater and } \\
\text { Rainwater } \\
\text { harvesting. } \\
\end{array}$ & $\begin{array}{l}\text { - Water treatment. } \\
\text { - Creation of the } \\
\text { lake / reservoir in } \\
\text { the campus area as } \\
\text { a water reservoir. }\end{array}$ & $\begin{array}{l}\text { - Water treatment. } \\
\text { - Creation of the lake } \\
\text { / reservoir in the } \\
\text { campus area as a } \\
\text { water reservoir. }\end{array}$ \\
\hline Transportation & $\begin{array}{l}\text { - Pedestrian Ways } \\
\text { - Limitation of } \\
\text { parking spaces } \\
\text { (parking priority) } \\
\text { - Restrict vehicle } \\
\text { access to the } \\
\text { campus. } \\
\text { - Operation of the } \\
\text { bus in the campus. } \\
\text { - Operation of bicyle } \\
\text { on campus. }\end{array}$ & $\begin{array}{l}\text { - Pedestrian Ways } \\
\text { - Limitation of } \\
\text { parking spaces } \\
\text { (parking priority) } \\
\text { - Restrict vehicle } \\
\text { access to the } \\
\text { campus. } \\
\text { - Operation of the bus } \\
\text { in the campus. } \\
\text { - Operation of bicyle } \\
\text { on campus.. }\end{array}$ & $\begin{array}{l}\text { - Pedestrian Ways } \\
\text { - Limitation of } \\
\text { parking spaces } \\
\text { (parking priority) } \\
\text { - Restrict vehicle } \\
\text { access to the } \\
\text { campus. } \\
\text { - Operation of the bus } \\
\text { in the campus. } \\
\text { - Operation of bicyle } \\
\text { on campus.. } \\
\end{array}$ & $\begin{array}{l}\text { - Pedestrian Ways } \\
\text { - Limitation of } \\
\text { parking spaces } \\
\text { (parking priority) } \\
\text { - Restrict vehicle } \\
\text { access to the } \\
\text { campus. } \\
\text { - Operation of the bus } \\
\text { in the campus. } \\
\text { - Operation of bicyle } \\
\text { on campus.. }\end{array}$ & - Pedestrian Ways \\
\hline Education & $\begin{array}{l}\text { - conscious soul } \\
\text { planting ecological } \\
\text { sustainability in the } \\
\text { curriculum subjects. } \\
\text { - sustainability } \\
\end{array}$ & $\begin{array}{l}\text { - conscious soul } \\
\text { planting ecological } \\
\text { sustainability in the } \\
\text { curriculum } \\
\text { subjects. } \\
\end{array}$ & $\begin{array}{l}\text { sustainability entered } \\
\text { into subjects. } \\
\text { Organizing seminars } \\
\text { and conference on } \\
\text { sustainability. } \\
\end{array}$ & $\begin{array}{l}\text { - conscious soul } \\
\text { planting ecological } \\
\text { sustainability in the } \\
\text { curriculum subjects. } \\
\text { - sustainability entered } \\
\end{array}$ & $\begin{array}{l}\text { - sustainability entered } \\
\text { into subjects. } \\
\text { - Education with the } \\
\text { planting of trees by } \\
\text { the students. }\end{array}$ \\
\hline
\end{tabular}




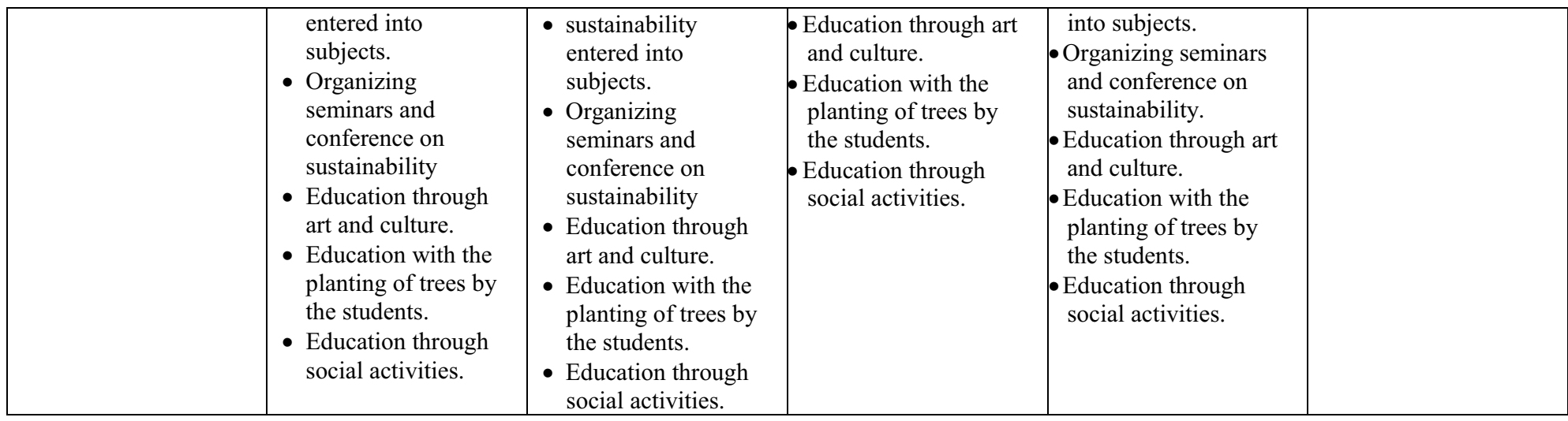




\section{Conclusions}

The conclusion from this study that the university campus in Indonesia have applied the ecological architecture concept in several aspects. There are some similarities and differences in the application of some aspects. Application of the ecological architecture concept not in all parameters, which became a case study. Similarity application of the concept of ecological architecture is done on the concept of waste management and garbage and the concept of energy efficiency and climate management. While the parameters of the concept of sustainability in the process of university education in Indonesia is still a bit applications done.

a) Parameter of setting and infrastructure applied with the preparation of an integrated campus master plan, the determination percentage green open space, application of green building concept.

b) Parameter of energy and climate change applied with bio diversity and biodiesel, use of energy saving lamps and tools, eco-friendly materials, optimizing natural lighting, natural heating and cooling optimization, vegetation.

c) Parameter of waste treatment applied with waste water treatment and garbage, paperless policy, composting.

d) Parameter of water treatment applied with water treatment instalation, create lakes or ponds in the campus area as water storage, rainwater catchment manufacture, utilization of greywater and rainwater harvesting.

e) Parameter of transportation applied with a pedestrian ways network, restricted parking area (parking priority), restricted vehicle access to the campus, the operation of campus bus, operation of bicyle on campus.

f) Parameter of education applied with carried out by planting the soul conscious of ecological sustainability in the curriculum subjects, sustainability entered into courses, organization of seminars and conference on sustainability, education through art and culture. Education and tree planting by students. Education through social activities.

Recommendations from this study is that a university campus building design should be able to optimize the application of the ecological architecture concept on all aspects of the design. This is because the importance of a common awareness related to the necessity of preservation of our environment. Application of the this concept is done since the stages of determining the site location and setting until the design of Detailed Engineering Design so that all parameters of that concept can be applied optimally on the university building design in Indonesia.

\section{References}

1. Bahry, Donna. L, "Crossing Border: the Practice of Comparative Research", in Jarol B. Manheim and Richard C. Rich, Empirical Political Analysis: Research Methods in Political Science, London, Longman Publisher. (1995)

2. Hermann, Richard, K., "Linking Theory to Evidence in International Relations", in Walter Carlsnaes, Thomas Risse and Beth A. Simmons,Handbook of International Relations, London: SAGE Publication. (2002)

3. Lijphart, Arend., "The Comparable-Cases Strategy in Comparative Research", dalam Comparative Political Studies. Sage Publications Inc, Vol.8:No.2. (1975) 
4. Frick, Heinz., Tri Hesti Mulyani., “Arsitektur Ekologis, Konsep Arsitektur Ekologis di Iklim Tropis, Penghijauan kota dan kota ekologis, serta energi terbarukan." Penerbit Kanisius dan Soegijapranata University Press, Semarang (2006)

5. Frick, Heinz. "Dasar-Dasar Eko-Arsitektur". Edisi ke-1. Yogyakarta: Yayasan Kanisius, (1998)

6. Sue Roaf, David Crichton, Fergus Nicol, "Adapting Building and Cities for Climate Change", Burlington: Elsevier, (2005)

7. Ulla Myhr, Rolf Johannson, "Ecoeffect for Outdoor Environments: The Process of Tool Development, Environmental Impact Assesment Review”. Elsevier, available online at www.science direct.com. (2008)

8. Yeang, Ken, Designing With Nature, “The Ecological Basic for Architectural Design”, Mc. Graw Hill. Inc., (1995).

9. Regulation of Minister of Public Work and RI No.02 Tahun 2015 about Green Building (2015). 